\title{
Primary Membranous Glomerulonephritis in a Young Patient with Proteinuria
}

Ece ÜNAL ÇETİN ${ }^{1}$, Adil Uğur ÇETİN ${ }^{2}$

${ }^{1}$ Emet Dr. Fazıl Doğan State Hospital, Kütahya, Turkey

${ }^{2}$ Çanakkale Onsekiz Mart University, Department of Internal Medicine, Çanakkale, Turkey

\begin{abstract}
Membranous nephropathy is a common form of glomerulonephritis that typically presents with nephrotic syndrome between the $3^{\text {rd }}$ and $5^{\text {th }}$ decades and one-third of patients experience spontaneous remission. Here, a patient with primary membranous nephropathy is presented.
\end{abstract}

Turk J Int Med 2021;3(Supplement 1):S65-S66 DOI: $\underline{10.46310 / \text { tjim. } 876058}$

Keywords: Dolicoectasia, Vertebrobasilar Artery, Headache

\section{Introduction}

Under physiological conditions, daily protein excretion with urine is below $150 \mathrm{mg}$. Detecting protein excretion above this value in repeated measurements, i.e., proteinuria, should not be ignored and further evaluation should be made. Protein excretion above this level is generally an important indicator of underlying kidney damage. The commonly used method to evaluate whether the protein excretion in urine is within normal limits is the measurement of protein in 24-hour urine. ${ }^{1}$

\section{Case Report}

A 31-year-old patient without a known illness and no regular medication was admitted to the outpatient clinic with proteinuria. The patient did not have any complaints other than foaming in the urine and a new rash on the nasal wings. There was no history of a recent upper respiratory tract infection or arthritis. No pathology was found on physical examination. The test results of the patient are given below: urea: $24 \mathrm{mg} /$ $\mathrm{dL}$, creatinine: $0.7 \mathrm{mg} / \mathrm{dL}$, albumin: $2.9 \mathrm{~g} / \mathrm{dL}$, sodium: $141 \mathrm{mmol} / \mathrm{L}$, potassium: $4.4 \mathrm{mmol} / \mathrm{L}$, LDL: 259, HDL: $40 \mathrm{mg} / \mathrm{dL}$, TSH: 2, PTH: 57, 
hemoglobin: $15.2 \mathrm{~g} / \mathrm{dL}, \mathrm{MCV}$ : 82, IgM: 31, IgG: 644, IgA: 205, C4: 28, and C3: 129. The protein excretion was $9 \mathrm{~g}$ in 24-hour urine. RF, ANA, PR3 ANCA, MPO ANCA, HBsAg, anti-HIV, and anti-HCV were negative. ACE inhibitor and acetylsalicylic acid were initiated for the patient. The patient, who was found to have proteinuria at the nephrotic level, hyperlipidemia, and hypoalbuminemia, was referred to a kidney biopsy to investigate proteinuria's etiology. The pathology result was determined as IgG4 + membranous glomerulonephritis. During the controls, the patient, who was considered low risk, had a 24hour urine protein of $1.5 \mathrm{~g}$, was started on $10 \mathrm{mg}$ atorvastatin. A dietician regulated the patient's diet, and 24-hour urine control was recommended. In the patient's follow-up, phospholipase A2 was positive, and it was followed up as idiopathic membranous glomerulonephritis.

\section{Discussion}

Membranous nephropathy is the leading cause of nephrotic syndrome in the adult population. ${ }^{2-5}$ The disease is characterized by the deposition of immune complexes outside of the glomerular basement membrane. This accumulation causes the glomerular filtration barrier to lose its function and this results in proteinuria. ${ }^{3-5}$ It is generally classified as membranous nephropathy, primary or secondary membranous nephropathy. There is no known etiology in $70-80 \%$ of cases. If a secondary cause cannot be determined, this group is classified as "Primary membranous nephropathy"., 4,7 In $70 \%$ of adult patients, phospholipase A2 in podocytes has been shown to be the target antigen in primary membranous nephropathy. ${ }^{8}$

In conclusion, glomerulonephritis should be considered in every patient with proteinuria. Patients should be directed to biopsy before progressing to end-stage renal disease, and they should be followed up and treated.

\section{Conflict of Interests}

Authors declare that there are none.

\section{Acknowledgment}

This study has been presented in $17^{\text {th }}$ Uludag Internal Medicine National Winter Congress, $6^{\text {th }}$ Bursa Family Medicine Association National Congress, $11^{\text {th }}$ Uludag Internal Medicine Nursing Congress, 5-7 March 2021, Bursa, Turkey.

\section{References}

1. Steinhäuslin F, Wauters JP. Quantitation of proteinuria in kidney transplant patients: accuracy of the urinary protein/creatinine ratio. Clin Nephrol. 1995 Feb;43(2):110-5.

2. Hoxha E, Harendza S, Pinnschmidt $H$, Panzer U, Stahl RA. PLA2R antibody levels and clinical outcome in patients with membranous nephropathy and non-nephrotic range proteinuria under treatment with inhibitors of the renin-angiotensin system. PLoS One. 2014 Oct 14;9(10):e110681. doi: 10.1371/journal. pone.0110681.

3. Ronco P, Debiec H. Pathophysiology of extramembranous glomerulopathies. Fifty years of progress, from laboratory to patient. Biol Aujourdhui. 2013;207(4):249-59 (in French). doi: 10.1051/ jbio/2013025.

4. Hoxha E, Kneißler U, Stege G, Zahner G, Thiele I, Panzer U, Harendza S, Helmchen UM, Stahl RA. Enhanced expression of the M-type phospholipase A2 receptor in glomeruli correlates with serum receptor antibodies in primary membranous nephropathy. Kidney Int. 2012 Oct;82(7):797-804. doi: 10.1038/ ki.2012.209.

5. Bomback AS, Gharavi AG. Can genetics risk-stratify patients with membranous nephropathy? J Am Soc Nephrol. 2013 Jul;24(8):1190-2. doi: 10.1681/ ASN.2013060576.

6. Debiec H, Hanoy M, Francois A, Guerrot D, Ferlicot S, Johanet C, Aucouturier P, Godin M, Ronco P. Recurrent membranous nephropathy in an allograft caused by $\operatorname{IgG} 3 \square$ targeting the PLA2 receptor. J Am Soc Nephrol. 2012 Dec;23(12):1949-54. doi: 10.1681/ ASN.2012060577.

7. Larsen CP, Messias NC, Silva FG, Messias E, Walker PD. Determination of primary versus secondary membranous glomerulopathy utilizing phospholipase A2 receptor staining in renal biopsies. Mod Pathol. 2013 May;26(5):709-15. doi: 10.1038/modpathol.2012.207.

8. Beck LH Jr, Bonegio RG, Lambeau G, Beck DM, Powell DW, Cummins TD, Klein JB, Salant DJ. M-type phospholipase A2 receptor as target antigen in idiopathic membranous nephropathy. N Engl J Med. 2009 Jul 2;361(1):11-21. doi: 10.1056/NEJMoa0810457. 